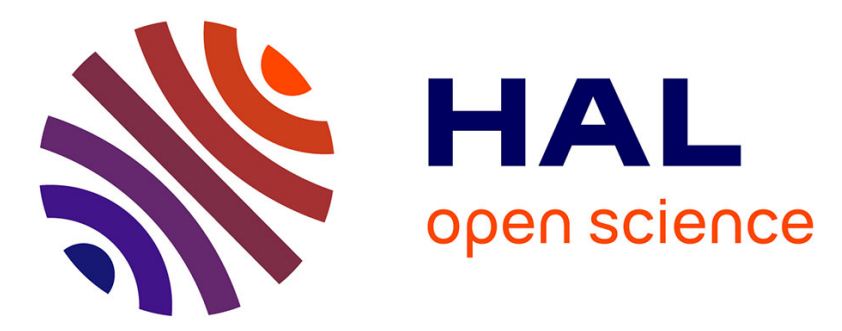

\title{
RETHINKING REGIONAL TELEVISION INTERCULTURAL CHALLENGE IN THE FACE OF MEDIA PROFUSION
}

Jacques Guyot

\section{- To cite this version:}

Jacques Guyot. RETHINKING REGIONAL TELEVISION INTERCULTURAL CHALLENGE IN THE FACE OF MEDIA PROFUSION. Javnost. The public., 1998, Vol. 5 (n 2), p. 61-71. halshs00657454

\section{HAL Id: halshs-00657454 \\ https://shs.hal.science/halshs-00657454}

Submitted on 6 Jan 2012

HAL is a multi-disciplinary open access archive for the deposit and dissemination of scientific research documents, whether they are published or not. The documents may come from teaching and research institutions in France or abroad, or from public or private research centers.
L'archive ouverte pluridisciplinaire HAL, est destinée au dépôt et à la diffusion de documents scientifiques de niveau recherche, publiés ou non, émanant des établissements d'enseignement et de recherche français ou étrangers, des laboratoires publics ou privés. 


\title{
RETHINKING REGIONAL TELEVISION INTERCULTURAL
CHALLENGE IN THE FACE OF
MEDIA PROFUSION JACQUES GUYOT
}

\begin{abstract}
In the context of internationalisation of audio-visual media, standardisation of exchanges and contents is also accompanied by a re-strengthening of local cultures. The claims for cultural and linguistic idiosyncrasies are directly linked to the development of regional television. Like in many other European regions, in Brittany (France), all the prerequisites seem fulfilled to launch a channel dedicated to the promotion of Breton culture and language. However, many uncertainties weigh on such a project. The size of the regional market may, of course, be an obstacle to financial

viability. But, above all, the notion of identity is quite problematic in the construction of a regional media space:

does it constitute a sufficiently solid and homogeneous base - from a sociological, cultural and linguistic point of view - to construct original television programming models which reflect the variety of social realities and cultural
\end{abstract}

Jacques Guyot is Senior Lecturer at the University of Rennes, Haute Bretagne. 


\section{Introduction}

Current discourse on digital technologies forecasts a brighter future for users (credited with an unquenchable demand for audio-visual and multimedia products) and also predicts radical change in behaviour and ways of thinking. Indeed, this technocratic and positivist ideology is not really new, even though it makes us forget the fact that the meaning of "digital" has changed. Far from High Definition Television which was supposed to bring movie quality to the household in the 1980s, it is now synonymous with multiplication of channels. Of course, this development has a number of consequences regarding content: how is it possible to provide these channels with new broadcasts when, long before the advent of satellite broadcasting, there already was a shortage of television programmes? Thus, regional television arrives just at the right moment to fill channel space.

However, beyond post-MacLuhanian prophecies, the current evolution offers new opportunities for the expansion of television systems, particularly in regions where the state of technology (e.g. television broadcasting networks, audio-visual production tools) now provide an outlet to those who wish to give momentum to more regional or even local projects. The dreams of the 1970s of user-friendly small community media are being updated: they now rely on linguistic and cultural idiosyncrasies as the ultimate bastion against international standardisation. Moreover, these identity claims meet with a favourable echo, both among television broadcasters and programme or service providers who are eager to link their international development strategies to regional dynamics, among big regional businessmen who are seeking cultural legitimacy and also among local politicians who want to give a humanistic sense to decentralisation policies.

This is the case of Brittany, in France, where all the technical and socio-political prerequisites for creating a regional channel seem to be fulfilled. However, the existence of favourable factors is a very fragile thing: as a matter of fact, nobody can really determine whether such a project derives from an objective correlation between a technical supply and a social demand or whether it is just a matter of circumstances. Among others, economical uncertainties weigh on a market whose level of fragmentation may be an obstacle to financial viability.

This particular situation raises three kinds of questions. First, what space does the internationalisation of audio-visual systems leave to regional media? Second, what part can existing networks and production facilities play within this regional positioning? And then, third, does the very notion of regional identity constitute a sufficiently solid and homogeneous base - from a sociological, cultural and linguistic point of view - to build up original television programming models that can reflect the variety of social realities and cultural constructions?

\section{The Paradoxes of Internationalisation}

Research on the internationalisation of communication suggests that the globalisation of economy and culture, as in the audio-visual field, is a major factor in the standardisation of exchange and of content, and greatly contributes to accelerate the processes of acculturation. At the same time, this levelling is accompanied by a return in the strength of local identities (Mattelart 1994). If the nature of this apparently contradictory double movement primarily benefits large international media groups, 
the new expressions of the "local" which, in its linguistic, cultural and social components, arise here and there within the intersections of market communication flow, are quite surprising because of their variety, their singularity and expressive richness, or sometimes just by their very existence.

This revenge of cultures, in the terms of Armand Mattelart (1994), lies within the general problematics of the return of the subject, as theorised by many ethnologists and sociologists who minutely observed and analysed the murmuring practice of individuals and social groups (e.g. Hoggart 1979; De Certeau 1984). This centring on the local, which can be interpreted as a particular reaction against the deterritorialisation of traditional social and cultural spaces caused by the internationalisation of communication systems, favours localism over transnationalism, proximity over distance, the user-friendliness of a personalised social link over anonymity of immaterial networks.

The practices of users already illustrate this trend. Presently, only considering French-speaking satellite television operations, it is possible to view more than 62 thematic channels. In spite of this media profusion, few audience members zap. This is what experts in selling advertising airtime - who are attentive observers of television practices - notice when they say: "We already know that, in countries where each household can get 50 to 60 channels, TV consumption focuses on an average of 8 to 10 channels: 1 or 2 general-interest national channels, 1 or 2 channels dedicated to fiction, and the rest are thematic channels" (Moulard 1997, 77). In short, the priority given to general-interest terrestrial national channels by viewers does not imply any drastic change in media planning from advertisers. This very selective but somewhat classical choice can be partly accounted for: on the one hand, time allotted to television consumption is not extensible, on the other hand, general-interest national terrestrial television - whether it is pubic service or private - still is for many viewers the reference model par excellence. ${ }^{1}$

Another point deserves to be mentioned is that satellite and cable TV networks are aimed at solvent customers. Therefore, the economical factor plays an important part, above all when one can get "free" terrestrial channels which offer a wide variety of programmes. The transition to a market economy most likely constitutes an obstacle in many European countries which are still deeply marked by public broadcasting service traditions. Moreover, in the general context of audio-visual and telecommunication deregulation, the issues of television content or the development of digital video broadcasting (DVB) are seldom subjected to any critical public debate. Within the logic of economical liberalism, the solvent consumer is the one who is supposed to make the ultimate choice, thus absolving programme producers and broadcasters as well as multimedia groups or politicians of any ethical responsibility. In this marketable extension of taste and democracy, the client is expected to legitimise the whole system very syllogistically: the client chooses from the profusion of images and since he pays for what he watches, what he views is good. If the quality of programmes is so often criticised by people, it may be a sign that the economical paradigm does not necessarily meet their expectations: because they are also citizens, viewers question the pseudo freedom which has been granted to them. It may be a way to interpret their reluctance towards multimedia and satellite equipment which represents an expensive investment for a mediocre qualitative profit, to say nothing about interference with other everyday activities. 
A surprising phenomenon deserves to be underlined because it clearly illustrates one of the paradoxical effects of the globalisation of audio-visual industries: the new interest people show in "proximity" news. Confronted with major information broadcasters like CNN, and also TF1 and France 2 evening news which include many subjects dedicated to international events, the " 6 to 7 PM news" produced and broadcast by France 3 meets with unequalled success: from 29\% of market share in 1990, regional news reached $43,7 \%$ in 1996, i.e. a larger percentage of the market than France 2 and just behind TF1. The rise of the "regional" which also affects thematic magazines like "Couleurs Pays" undoubtedly strengthens France 3 regional network's advance. But it also forces national terrestrial channels to consider a strategy for decentralisation of information. If France 2 has had for a long time regional offices which supply subjects to its national edition, the private channel M6 recently decided to launch a series of local editions in more than 10 cities (including Nantes and Rennes); these urban news broadcast at 8:30 p.m. five days a week and aim to attract youngsters through short video reports on local cultural life. TF1 and LCI (a satellite news channel) have chosen a different approach and decided to subcontract with "Master Infos," a Quimper-based audio-visual company to produce short video reports on social and cultural Breton events. In 1997, 720 video reports were broadcast, 520 of them just for TF1; for the Breton viewer, the commercial channel can offer a very panoptic vision of information, from international affairs to national events without neglecting what happens in "provinces" like Brittany.

Proximity information as well as news on local and regional cultural issues are now major stakes in the development strategies of general-interest national terrestrial channels. Satellite and cable television networks have already taken the dynamics of the "local" into account since it can help the public make a choice among existing systems. For example, Bouygues who owns TF1 is planning to launch a Breton channel for two hours a day on TPS (Télévision par satellite). But more immediately, the 64 football matches of the World Cup, broadcast in June/July 1998 on Eurosport (a subsidiary of TF1, Canal Plus and the American TV channel ESPN) will be processed in Breton. This experiment is an interesting real-life test since the cost is limited to audio translation.

\section{Television and Cable in Brittany}

In the competition between national terrestrial channels to find the appropriate regional strategy, France 3 has a real advantage due to the precedence of a dense network which has been gradually set up since 1975. In September 1983, eight different regional programmes started taking over from the national Parisian edition between 5 and 8 p.m. In 1990, local editions were launched to compete against M6. Of the 19 local editions, 3 of them are located in Brittany (Estuaire in Nantes, Iroise in Brest and Haute Bretagne in Rennes). They are usually broadcast during prime time and last around 5 minutes.

With 13 regional editorial boards, 25 regional news desks (the bureaux régionaux d'information or BRI produce and broadcast news programmes) and 56 permanent offices employing 1 or 2 journalists in charge of sending images through audio-visual markers (Bornes audio-vidéo, or BAV), the third channel is presently number one in terms of regional setting up in France.

As for programmes, France 3's policy is dictated by its public service television statute. But because it was created as a decentralised channel ${ }^{2}$ it also has a number of 
specific missions. Therefore, although the grid is mainly composed of national programmes, the regional editorial boards broadcast almost 15 hours weekly of regional production (news and magazines). Part of this total is produced in Brittany: France 3 Ouest produces around 450 hours a year of regional and local news and 250 hours of magazines (50 of them being in Breton). This programming policy promotes interregional exchanges but it also illustrates a very Jacobinistic conception of regional television.

As for cable television, the development is very new. Within the last ten years, eight Breton cities chose cable technology (average penetration rate of $22 \%$ ). Of these, only three have a local channel which produces and broadcasts brief news reports on local life: Rennes with TV Rennes, Brest with Brestel and Lorient with Canal local. As a matter of fact, cable-television networks are usually connected to satellites in order to offer subscribers a selection of thematic channels. As such, they are directed at solvent customers. Even when there is a "proximity" channel, the few minutes of daily magazines, generally dedicated to local news, are broadcast several times during the day and are lost in the flow of standardised cheap international programmes. This disproportion can be explained by economical factors inasmuch as production costs are very high: news, be it local or not, implies teams of skilled journalists as well as technical facilities which many urban communities cannot afford. Therefore, large cities like Nantes have given up the idea of launching a local television channel.

However, one thing to the credit of these networks is that they do exist and, thanks to a new interest for multicultural issues only, deserve to be better used, mainly by calling on other cultural, social and economical actors. Moreover, in spite of reservations, six new urban projects are presently being studied in Quimper, Saint Brieuc, Hennebont, Larmor, Inzinzac and Vannes, thus possibly soon bringing the total number of Breton cable television cities up to 14 . One of the reasons mentioned is that many towns think that this distribution system is the ideal answer to the aesthetic problems caused by the development of satellite dishes blossoming on balconies and on rooftops. Another argument acknowledges that the typical solvent clients for this service live precisely in the town centre, or even in the newly-built suburbs where upper-middle class like to settle.

\section{Cinematographic Culture, Audio-visual Production and Minorities}

When compared with other regions, Brittany is all but a desert in the field of media culture. In this way, even though the Breton cinematographic movement enjoyed varying fortunes, it cannot be dismissed as a utopian dream and Brittany did not only serve as a giant outdoor studio for the shooting of films built on a very exotic vision of Bretonhood (Michon 1996). It also is a region which quite early nourished a genuine reflection on the future of cinema. In the 1920s, from the peninsula of Crozon where he had retired, the poet Saint-Pol-Roux, a fervent admirer of French cinematographic avant-garde leader Abel Gans and a friend of André Antoine, the film director and founder of the Free Theatre, started writing for the review Mercure de France a series of articles which is still one of the more remarkable anthologies on cinema (Saint-PolRoux 1972).

The many attempts to set up a "Breton audio-visual industry" - mainly with the creation of the transient company "Brittia Films" by the 3 Caouissin brothers in 1950 
- seem to be getting a second life over the last few years. Two factors show the vitality of initiatives and experiments carried out on the issues of audio-visual media development in relation with regional identity: the birth of film festivals and the emergence of a varied production sector.

In 1978, Douarnenez, a small fishing harbour located at the western tip of Brittany, opens the first movie festival devoted to national minorities. The first edition offers a selection of films from Quebec. Every year, the festival tries to focus on the way movies express and represent minority peoples or ethnic groups such as the Indian nations, the European gypsies, the Afro-American, the Basques, the Australian Aborigines, the Palestinians or the Welsh in July 1998. Following the example of Douarnenez, the "Festival des trois continents" inspired by third-world topics opens in Nantes in 1979, then the "Rencontres Arts et Cinéma" in Quimper in 1983, the "Short-feature festival" in Brest (1985) and "Travelling" in Rennes (1989). Thus, five nationally and internationally-known film festivals offer a selection of audio-visual productions dedicated to cultural minority issues and show a very open-minded and curious attitude towards the peoples in the world.

In the same way, more than 30 companies work for the audio-visual production industry. Among them, 13 independent companies gathered within a professional association (Association des producteurs audiovisuels de Bretagne or APAB) in order to be present on European and national markets and also to weigh on regional cultural policies. Though all of them have a producer's card issued by the Centre National de la Cinématographie, very few make a full-time living from audio-visual production.

Most of these companies were founded over the last 5 years and they are likely to accompany the development of regional television. However, no information is available on their business activities. Hence the concern of academic research to draw up a thorough survey of audio-visual production: what is the value of these companies in economical terms, but also in terms of volume and types of production? What kinds of problems do they have when dealing with financial institutions? How are movie and video productions distributed and broadcast? What is it like to produce in regions? Until now, there has been no prospective study or collective reflection on possible trends to follow in order to view the role of audio-visual industries within the general problematic of regional cultural and economical development. In the view of the initial results from this research project, the 13 companies belonging to the APAB produced 46 hours of television programmes in 1997 (versus more than 400 in Galicia), i.e. a total that would be barely sufficient to provide a regional channel with a few minutes of daily programmes. ${ }^{3}$ However, the very existence of these companies reveals that the productions are extremely varied: long and short feature films, cartoons, documentaries, news reports, video art, advertising, institutional films (more than 600 units in 1997) or even live and recorded broadcasting of musical, sports and political events. All this is possible because there are technical facilities as well as skilled staff (producers, film directors, technicians and artists) who are quite familiar with new digital technologies. ${ }^{4}$

\section{Television and Ethnicity}

All the elements linked to technique and audio-visual facilities are undoubtedly major advantages in the possible development of a regional channel or local television networks. But they would be useless without a constructive reflection on the role that 
audio-visual tools can play in regions: in other words, even if the question may seem provocative, what can be the use of having a television channel in Brittany? As the researcher Pierre Musso reminds us: "Region makes television, television does not make the region" (Musso 1995, 179).

Until now, mostly for historical and political reasons, the debate focused on the problem of news in regions. Within this particular context, cultural idiosyncrasies including its linguistic aspects - were rarely taken into account. Moreover, whenever the question of setting up new local televisions is raised, the national regulating authorities (Conseil Supérieur de l'Audiovisuel) often tend to favour projects that are brought by economically wealthy urban areas rather than those carried by cultural or linguistic communities. Hence the strange paradox: while the number of channels increases exponentially due to digital technology, the opportunities for cultural and linguistic minorities to express themselves seem to shrink (Cheval 1996; Morley 1997). Here again, the economic paradigm leads the development of networks and digital video broadcasters are mostly interested in solvent customers to whom they can offer international second-market television productions. Following the example of free radio, there is a danger that local televisions do serve, sooner or later, the interests of private groups. Presently, digital television has the extreme advantage of allowing the recycling of programmes: stocks of long-feature films or reconstruction of thematic channels from the grids of general-interest televisions owned by multimedia groups.

Brittany which is reputed to have a strong cultural and linguistic identity can take up the challenge of building a media space in close relation to its own social reality, its own economic concerns and its own imaginary. The twentieth anniversary of the Breton Cultural Charter, first ratified in 1977 by former President Giscard d'Estaing and the representatives of five General Councils and the Regional Council, deals with this questioning. The preliminary document, entitled "Which Breton culture for the 21st century?" and which will constitute the guideline for the renewal of the Cultural Charter, integrates quite explicitly the role of media: out of the six points that are presently being discussed, chapter 2 is about "media and communication," chapter 3 "creation and creativity" is related to audio-visual tools and chapter 4 takes into account the notion of "cultural industries." Within that context, a commission is in charge of making concrete proposals for the creation of a Breton television channel. But, what does "Breton television" really mean?

Indeed, the very idea of building a regional audio-visual space implies removing the ambiguities which are inexorably linked to the notion of ethnicity. "When we carefully think about it, any kind of ethnicity is problematic, each one in its own way. And the particular ethnicity of Bretonhood ... is neither more nor less problematic than any other one," says sociologist Pierre-Jean Simon $(1979,5)$ for whom the image of the Breton used to function like such a "natural" and firmly fixed idea that it no longer needed to be clarified. Two of the elements that constitute the Breton ethnicity as they were listed and criticised by Simon may enlighten some of the tensions between the regional actors of the Breton cause: the territory and the culture.

Therefore, as far as the setting up of a Breton channel is concerned, which technical model should be taken? Terrestrial broadcasting for a complete and uniform cover of Brittany, urban cable-TV networks to reach selectively a larger and less scattered population or even hybrid systems which are more flexible to use but also more complicated to install? In the same way, which Brittany is it about? The administrative 
division thought by the State within its policy of regional development which comprises the four official Breton "départements" (Côte d'Armor, Finistère, Morbihan and Ille et Vilaine), the "Grand Ouest" corresponding to France 3 regional board, the historical Brittany which included Nantes and the Loire Atlantique, the Breton-speaking area westward a line splitting Brittany from Saint Brieuc to Vannes, or even coastal Brittany which contributed to the success of the tourist industry? All these visions correspond to political or sometimes historical divisions, but they are also the result of an eminently incarnate and subjective idea of what the "Breton territory" looks like, according to each inhabitant. However, the way the broadcasting area is marked out affects the type of programming policy.

As for the cultural aspect, it is quite problematic especially when the linguistic issue is tackled. A recent series of surveys carried out by the Breton section of the INSEE (Institut national de la statistique et des études économiques) ${ }^{5}$ draws up a clear-cut and somewhat pessimistic report on Breton language. Of a total of 534,000 persons who more or less understand Breton, 369,000 speak the language rather fluently (24\% of the population in Basse Bretagne), but two thirds of them are elderly people (over 60 ); moreover, only 268,000 can be considered "true native speakers" first because Breton is their mother tongue and secondly because they can practise it since they still live in Basse Bretagne (i.e. the traditionally Breton-speaking area). ${ }^{6}$ 40,000 persons were taught Breton in schools: more than $50 \%$ of them are under 30 years old and $25 \%$ live in non-Breton speaking areas. Among youngsters (under 16), 11,000 say they can understand and speak it and 5,000 are able to read it. The 1994 Insee inquiry shows that the transmission rate of the language from one generation to the other is very low $(3 \%)$ even though bilingual schools manage to attract more and more pupils (about $13 \%$ of annual growth for educational institutions like the pioneer association Diwan or bilingual classes in public or private schools which taught a total of 3,401 children and youngsters in 1996).

The situation is worrisome. On one hand, a public of elderly native speakers living in rural areas; on the other hand, youngsters who dwell in towns (including cities like Rennes where the Breton language was never spoken) and learn Breton in schools or evening classes, their mother tongue being French. This socio-cultural break must be taken into account since it will affect the role that television can play in a linguistic promotion. If there is a future for the Celtic language, it must first go through a original educational policy. Within this context, television can only be a counterpoint, thanks mainly to the existence of specific programmes designed to fix the young generation's language practice in everyday reality.

Finally, if the linguistic factor is an essential element in cultural identity, it is by no means an indispensable condition for belonging to Breton ethnicity. This crucial problem was pointed out by Michel de Certeau who wrote that "The language of autonomy is political" (De Certeau 1980, 138). In the mind of the French researcher who embodies a very original project of political anthropology, the ethnic group cannot be reduced to a mere academic subject, as most sociologists and ethnologists often study it. For de Certeau, the ethnic group is the result of what a group of people can define through an eminently political act, like some kind of challenge to exist. Therefore, because we focus excessively on the linguistic factor, we tend to forget that Breton people - but also any other group claiming its autonomy — can only define the cultural and linguistic terms of their existence within a democratic political public space. The Breton cause can gain its legitimacy, provided all the tensions between the different 
regional actors can be resolved and transformed into a favourable political balance of powers.

\section{France 3's Consideration for Regional Languages}

Before launching a Breton TV channel or network, a number of common places linked to cultural identities need to be clarified. As de Certeau pointed out, the ethnic question is above all a political one in the sense that "a policy is characterised by the articulation of tactics with a strategy." Within this context, autonomy is a matter of strategy, and language has to do with tactics. Of course, such a choice implies priorities: first exist politically speaking, even if it means postponing the process of Bretonisation for the time being. Presently, linguistic issues are being discussed by the members of the commission set up by the Cultural Charter and are far from being resolved. Although ancient identity claims are brought to light, intense tensions are expressed, for instance by the Breton militants who are very divided on the sense to give to a television project: traditionalists carrying an enchanted vision of an endangered Bretonspeaking rurality versus modernists, marked by the mythical S4C Welsh television model, underestimate of economic implications, bilingualism versus exclusive use of Breton, rural Breton versus the language taught in schools, type of target public, etc. At the moment, the debate is partially stuck in manoeuvring to win representation on behalf of a legitimacy gained on the ground of the defence of Breton language. ${ }^{7}$

Therefore, the policy conducted by France 3 Régions in the field of regional languages is less an example to follow than the illustration of the gap to fill in order to invent new models. The first experiment in Breton started in 1964. It was presented by Charlez Ar Gall within the regional news bulletin every Friday and lasted only 1 minute 30. This exceptional event was due to the strong personality of its two promoters: Charlez Ar Gall and the poet and writer Per-Jakez Elias. Both men had already directed a chronicle in Breton on "Radio Quimerc' $h$ " in Brest. Most likely, the interest of national authorities towards Breton was motivated by strategic reasons: indeed, the mid-1960s were times when television in France was in full expansion and a short programme in Breton could only convince people to buy a set. This is a way to interpret the extremely short time dedicated to this first weekly programme. In 1971, "Breiz o veva," a 15-minute magazine appeared on the screen every fortnight. However, the real change occurred after 1975 when France 3 Régions was endowed with a new legal framework which, for the very first time, takes the Breton language into account. Thus, article 16 specifies that "the television company contributes to the expression of the main regional languages spoken on the metropolitan territory" (Bilans du CSA 1994, 59). Nevertheless, the linguistic issue is considered as just one among many other public service obligations and no quotas are fixed. A comparison with other French regions shows that minority languages are marginalised. In 1995, 292 hours were broadcast in regional languages: 53 hours in Breton, 121 in Alsacian, 40 in Corsican, 22 in Provencal, 25 in Basque and 31 in Occitan. It again clearly illustrates the limits of promoting of minority cultures within a national television system but above all the extreme difficulty of actually decentralising the France 3 network.

Compared to other countries - almost 40 hours a week on the Welsh channel S4C and 16 hours a day for the autonomic Galican television (TVG) - the attitude of French authorities is very restrained. In both cases, however, these two specific channels were created in the context of laws granting political autonomy. 


\section{Conclusions}

The resolution of the linguistic issues cannot be separated from the general problematic of programming policies. A grid of programmes implies high costs, in terms of production, broadcasting and also purchase. At the economic level, local and regional communities cannot obviously afford to support such projects on their own budget. With broadcasting costs close to 650,000 dollars per year on satellite and a total budget of 80 million dollars for the poorest television broadcasters, other funds must be found. Otherwise, less ambitious projects can be launched, mainly on city cable television networks which, at the moment and in the best case, only produce a very small part of their programmes.

What the present situation shows is that it seems important to mobilise and use local and regional resources and facilities more systematically: the audio-visual archives of the Cinémathéque de Bretagne can be better exploited, catalogues of audio-visual productions must be constructed, institutions like the CCETT (Joint centre for the study of television and telecommunication) can provide technological expertise, exchange agreements with France 3 can be signed for instance in order to supply programmes just like the BBC does for the Welsh channel $\mathrm{S} 4 \mathrm{C}$, professional training in subtitling or dubbing can be developed, etc.

At the international or inter-regional level, co-operation must also be organised in order to launch co-productions and also to develop exchange markets. The existing networks which have been constituted around the Celtic countries or the Atlantic periphery may prefigure such exchanges, but they are too small to supply television channels which are naturally voracious media. Other regional spaces should be integrated to this system.

In this respect, regional television is still something to invent, mainly in the way to think content, programming, production and exchanges of programmes. It also remains to invent a television model that can serve a community and help promote its culture and language; it is all the more necessary in order not to leave the field to the sole initiative of commercial networks which will use the new interest in identities as a marketing tool.

The development of regional television is not strictly conditioned solely by technical determinism. The great number of innovations in the field of new digital technologies undoubtedly open up opportunities in terms of television broadcasting, teledistribution, hybrid systems or multiplication of channels. However, they are just the elements, essential surely but not the only ones, of a puzzle which is also composed of political, economical, social and cultural pieces. Therefore, rethinking television on the local or regional scale implies, among other things, questioning the way cultural identities build themselves, with, as a corollary, the obligation to weave relationships, not only in its own region but also with other cultural spaces. As Armand Mattelart says: "When the 'local' is used to drive back the advances of the 'world-wide' or the 'international', one may find oneself excusing a movement that tends to diminish meaning and the capacity to act in concrete situations. The 'local' is of no real interest except where it allows a better grasp, by virtue of proximity, of the interaction between the abstract and the concrete, between experience and the universal, between the individual and the collective" (Mattelart 1994, 198). As a matter of fact, withdrawing into one's cultural identity can lead to the worst forms of nationalism. To avoid this risk, one must remember that a well-balanced media system can only be built within a democratic public space. 


\section{Notes:}

1. Moreover, most heavy viewers can be found among elderly people who stay on average 248 minutes per day in front of their television sets (Les chiffres clés de la télévision et du cinéma, 1995, 183).

2. This decentralization policy has been often criticized because, for a long time, the term was used to conceal a reinforced control of information in french regions by the political power. France 3 régions was in fact created as the media facet within the French policy of national and regional development. See further de Tarlé (1979).

3. The 46 hours of programmes were mainly broadcast on national television channels: "Lazennec Bretagne" produced 15 hours (34 episodes of a 26-minute scientific magazine designed for children) for France 3 national grid and "Master Info" sold 18 hours of news to TF1 and LCl.

4. A number of institutions and associations also make things easier: "Actions Ouest" gathers more than 400 comedians and film technicians, the Regional Movie Workshop (ARC) in Quimper provides technical facilities and advice, "Steredenn" is in charge of distributing Breton audiovisual productions and the "Cinémathéque de Bretagne" manages an important collection of audiovisual breton archives that can be used to make documentaries.

5. Propos sur la langue Bretonne. 1990. In Les dossiers d'octant, revue de I'Insee-Bretagne, 23: La pratique du breton dans les communes. 1991. In Octant, revue de I'Insee-Bretagne, 48; La connaissance du breton. 1994. In Octant, revue de I'Insee-Bretagne, 56-57.

6. Some 1.5 million people live in that area.

7. Such tensions also exist among other actors of Breton cultural and political life. The interview of Jean-Yves Cozan, the former president of the General Coucil of Finistčre, illustrates a very exclusive analysis of Breton identity; "High Brittany is the suburb of Paris. . I think that Rennes is not a Breton city. If the inhabitants of Rennes feel they are Bretons, well fine, but I belong to Low Brittany [the breton-speaking area] first" (Source: Ar Men, nr. 89, November 1997).

\section{References:}

Bilans de CSA. 1994. La sociéte nationale de programme France 3. Paris: CSA.

Cheval, Jean-Jacques. 1996. Médias audiovisuels françis et langues réionales minorisées. In A. Vieut (ed.), Langues d'Aquitaine: dynamiques institutionnelles et patrimoine linguistique, 197-242. Bordeaux: Éditions de la maison des sciences de l'homme d'Aquitaine.

De Certeau, Michel. 1980. La culture au plurie/. Paris: Christian Bourgois Éditeur.

De Certeau, Michel. 1984. The Practice of Evefyday Life. Berkeley: University of California Press.

De Tarle, Antoine. 1979. The Monopoly that Won't Divide. In A. Smith (ed.), Television and Political Life: Studies in Six European Countries, 41-45. London: Mac Millan Press.

Hoggart, Richard. 1970. The Use of Literacy. New York: Oxford University Press.

Matterlart, Armand. 1994. Mapping World Communication: War, Progress and Culture. Minneapolis: University of Minnesota Press.

Michon, Roland. 1996. Genése et structures de la production audiovisuelle en Bretagne. In Comunicación na periferia Atlántica, 281-287. Santiago de Compostela: Servicio de publicacións e intercambio científico.

Morley, David and Kevin Robins. 1995. Spaces of Identity: Global Media, Electronic Landscapes and Cultural Boundaries, London: Routledge.

Moulard, Cécile. 1997. Les annonceurs face au paysage audiovisuel numérique (PAN). MédiasPouvoirs 45, 76-80.

Musso, Pierre. 1995. Médias et formation des identités régionales en Europe. In J-P Saiez (ed.), Identités, culture et territoires, 169-185. Paris: Desclée de Brouwer.

Rochard, Yvon. 1997. Jean-Yves Cozan : l'identité régionale et la politique. Revue Ar Men 89, 22-29.

Saint-Pol-Roux. 1972. Cinéma vivant. Mortemart: Rougerie.

Simon, Pierre-Jean. 1979. Aspects de l'ethnicité bretonne. Plurie/ 19, 5-51. 